УДК 635.21:631.5

А.К. Горбунов, А.А. Васильев

УРОЖАЙНОСТЬ И КРАХМАЛИСТОСТЬ КЛУБНЕЙ КАРТОФЕЛЯ

В ЛЕСОСТЕПИ ЧЕЛЯБИНСКОЙ ОБЛАСТИ В ЗАВИСИМОСТИ ОТ ПРИЕМОВ АГРОТЕХНИКИ

Ключевые слова: картофель; крахмалистость клубней; срок и глубина посадки; площадь и уровень питания; протравливание семенного материала.

Введение. Картофель - одна из важнейших сельскохозяйственных культур Челябинской области. Площадь возделывания его во всех категориях хозяйств превышает 50 тыс. га. Однако урожайность остается невысокой (15 т/га) и неустойчивой по годам. Повышение урожайности и улучшение качества клубней - важная задача аграрной науки для более полного обеспечения населения картофелем.
Главным фактором, определяющим продуктивность и стабильность производства картофеля, является сорт [1]. Агроклиматические ресурсы региона позволяют возделывать ранние, среднеранние и среднеспелые сорта. Предпочтение следует отдавать сортам местной селекции, сочетающим высокую продуктивность и высокую адаптивность к конкретным почвенно-климатическим условиям [2]. По 
данным Р.Р. Галеева [3], за счет внедрения новых сортов достигается 30-50 \% роста продуктивности современного картофелеводства. Кроме того, для получения высоких урожаев клубней с повышенным содержанием крахмала в технологии возделывания картофеля важное место занимают сбалансированность минерального питания [4-5], сроки посадки и площадь питания растений [6-7].

Величина урожая определяется фотосинтетической деятельностью растений. Для реализации биологического потенциала возделываемых сортов (40-50 т/га) необходимо формировать посевы картофеля, обеспечивающие максимальное усвоение ФАР, путем подбора оптимального сочетания сроков и густоты посадки, уровня минерального питания и других элементов технологии с учетом плодородия и влагообеспеченности почвы.

Цель исследований. В 2011-2013 гг. нами проведены исследования по изучению влияния комплекса агротехнических факторов (срок, густота и глубина посадки, протравливание семенного материала и применение расчетных доз минеральных удобрений) на крахмалистость клубней картофеля в условиях лесостепной зоны Южного Урала.

Материал и методы. Закладку опыта, проведение анализов, учетов и наблюдений осуществляли в соответствии с общепринятыми методиками [8]. Математическую обработку данных проводили методом многофакторного дисперсионного анализа [9]. Почва опытного участка - чернозем выщелоченный среднесуглинистый с содержанием гумуса (по Тюрину) $5,90-7,26 \%, \mathrm{P}_{2} \mathrm{O}_{5}$ (по Чирикову) - 118-160, $\mathrm{K}_{2} \mathrm{O}$ (по Чирикову) - 193-257 мг/кг почвы, $\mathrm{pH}_{\text {сол }}=$ 5,12-5,20. Сорт картофеля Тарасов (среднеспелый). Предшественник - пар сидеральный (яровой рапс). Для посадки использовали клубни 50-80 г. Учетная площадь делянки $27 \mathrm{~m}^{2}$. Повторность опыта четырехкратная. Размещение делянок в повторениях систематическое. Содержание крахмала в клубнях определяли по удельной массе клубней [10].

Схема опыта. Фактор А - срок посадки: 1. Оптимальный (17-20 мая); 2. Поздний (1-5 июня). Фактор В - глубина посадки: 1. Мелкая (5-6 см); 2. Глубокая (10-12 см); Фактор С - протравливание семенных клубней: 1 . Без обработки (контроль); 2. Обработка клубней во время посадки препаратом ТМТД, ТПС (2,5 л/т). Фактор D - густота (схема) посадки: 1 . 49,3 тыс. клубней на 1 га $(75 \times 27$ см $) ; 2.70,1$ тыс. клубней на 1 га $(75 \times 19$ см). Фактор $\mathbf{E}-$ уровень минерального питания: 1 . Без удобрений (контроль); 2. Удобрения в расчете на урожай 25 т/га (в среднем за 3 года $-\mathrm{N}_{60} \mathrm{P}_{36} \mathrm{~K}_{60}$ );
3. Удобрения в расчете на урожай 40 т/га $\left(\mathrm{N}_{176} \mathrm{P}_{157} \mathrm{~K}_{234}\right)$.

Метеорологические условия отличались по годам исследований. По величине гидротермического коэффициента период активной вегетации (июнь-август) 2011 г. признан влажным $(\Gamma \mathrm{TK}=1,62), 2012$ г. - недостаточно влажным $(\Gamma \mathrm{TK}=0,90)$ и 2013 г. - умеренно-влажным $(\Gamma \mathrm{TK}=1,24)$.

Результаты и их обсуждение. Срок посадки картофеля позволяет влиять на весь комплекс факторов внешней среды (температуру, свет, влажность и др.). Он в значительной мере определяет начало вегетации, время уборки, величину урожая и его качество [11]. Поэтому выбор правильного срока посадки - важнейший фактор создания благоприятных условий для роста и развития растений, формирования высокого урожая и качества клубней [12].

Установлено, что посадка в оптимальные сроки (17-20 мая) увеличивала площадь листьев картофеля в среднем на 1,9 тыс. м $^{2} /$ га $(7,7 \%)$ по сравнению с посадкой 1-5 июня, создавая предпосылки для увеличения урожая и качества клубней [13]. Как следствие, отмечалось повышение содержания крахмала в клубнях в среднем на 0,16\% (урожайность картофеля при этом снижалась на 2,23 т/га), при заделке клубней на глубину 5-6 см - на 0,23 \%, на 10-12 см - на 0,09 \% по сравнению с поздней посадкой (таблица 1).

Вегетативное размножение картофеля объясняет высокую эффективность мероприятий, направленных на подавление первичной инфекции, находящейся на семенных клубнях [14]. В нашем опыте обработка семенного материала во время посадки картофеля фунгицидом ТМТД увеличивала урожай картофеля сорта Тарасов в среднем на 7,42 т/га при первом сроке посадки и на 2,92 т/га - при втором. Крахмалистость клубней при этом изменялась неоднозначно: при посадке 17-20 мая снижалась в среднем на 0,05\%, а при посадке 1-5 июня - на 0,02\%, то есть в пределах ошибки опыта. Наиболее существенное снижение содержания крахмала - в среднем на 0,23 \% (при посадке на глубину 5-6 см - на 0,29 \%, на глубину 10-12 cм - на 0,17\%) - отмечалось в 2011 году. Это, по нашему мнению, можно объяснить значительными прибавками урожая от протравливания семенного материала - в среднем на 5,82 т/га (при мелкой заделке - на 9,21 т/га, при глубокой посадке - на 2,43 т/га).

Многочисленные исследования свидетельствуют о том, что картофель хорошо отзывается на применение удобрений [15-16]. В нашем опыте применение минеральных удобрений в расчете на урожай 25 т/га повышало продук- 
тивность картофеля сорта Тарасов в среднем на 5,90 т/га (27,9\%), а на урожай 40 т/га - на 9,19 т/га (43,4 \%) по сравнению с неудобренным контролем. Крахмалистость клубней при этом снижалась незначительно - в среднем на 0,11 и
$0,25 \%$. Это согласуется результатами исследований И.С. Шатилова [17], по данным которого, сбалансированное питание картофеля позволяет избежать существенного ухудшения качества продукции.

Таблица 1 Урожайность картофеля сорта Тарасов при посадке во второй декаде мая в зависимости от приемов агротехники, т/га (в среднем за 2011-2013 гг.)

\begin{tabular}{|c|c|c|c|c|c|c|c|c|c|}
\hline \multirow{3}{*}{$\begin{array}{c}\text { Глубина } \\
\text { посадки } \\
\text { (В) }\end{array}$} & \multirow{3}{*}{$\begin{array}{c}\text { Протравли- } \\
\text { вание (C) }\end{array}$} & \multirow{3}{*}{$\begin{array}{l}\text { Схема по- } \\
\text { садки (D) }\end{array}$} & \multirow{3}{*}{$\begin{array}{c}\text { Уровень питания } \\
\text { (Е) }\end{array}$} & \multicolumn{6}{|c|}{ Срок посадки (А) } \\
\hline & & & & \multicolumn{3}{|c|}{ 17-20 мая } & \multicolumn{3}{|c|}{ 1-5 июня } \\
\hline & & & & $\begin{array}{c}\text { урожай, } \\
\text { т/га }\end{array}$ & $\begin{array}{c}\text { крахмал, } \\
\text { \% }\end{array}$ & \begin{tabular}{|c|} 
сбор \\
крахмала, \\
т/га
\end{tabular} & $\begin{array}{c}\text { урожай, } \\
\text { т/га }\end{array}$ & $\begin{array}{c}\text { крахмал, } \\
\text { \% }\end{array}$ & $\begin{array}{c}\text { сбор } \\
\text { крахмала, } \\
\text { т/га }\end{array}$ \\
\hline \multirow{12}{*}{$5-6 \mathrm{~cm}$} & \multirow{6}{*}{$\begin{array}{c}\text { Без } \\
\text { обработки }\end{array}$} & \multirow{3}{*}{$75 \times 27 \mathrm{~cm}$} & $\mathbf{N}_{0} \mathbf{P}_{0} K_{0}$ & 16,1 & 13,09 & 2,10 & 17,8 & 12,83 & 2,28 \\
\hline & & & $\mathrm{N}_{60} \mathrm{P}_{36} \mathrm{~K}_{60}$ & 22,2 & 12,94 & 2,86 & 23,2 & 12,73 & 2,95 \\
\hline & & & $\mathrm{N}_{176} \mathrm{P}_{157} \mathrm{~K}_{234}$ & 23,4 & 12,82 & 3,01 & 25,8 & 12,55 & 3,23 \\
\hline & & \multirow{3}{*}{$75 \times 19 \mathrm{~cm}$} & $\mathbf{N}_{0} \mathbf{P}_{0} K_{0}$ & 18,7 & 13,23 & 2,48 & 23,1 & 12,97 & 2,99 \\
\hline & & & $\mathrm{N}_{60} \mathrm{P}_{36} \mathrm{~K}_{60}$ & 23,3 & 13,09 & 3,05 & 28,8 & 12,86 & 3,70 \\
\hline & & & $\mathrm{N}_{176} \mathrm{P}_{157} \mathrm{~K}_{234}$ & 26,2 & 12,91 & 3,38 & 29,4 & 12,69 & 3,73 \\
\hline & \multirow{6}{*}{$\begin{array}{c}\text { ТМТД, ТПС } \\
(2,5 \text { л/т) }\end{array}$} & \multirow{3}{*}{$75 \times 27 \mathrm{~cm}$} & $\mathbf{N}_{0} \mathbf{P}_{0} K_{0}$ & 21,1 & 13,00 & 2,74 & 19,6 & 12,76 & 2,50 \\
\hline & & & $\mathrm{N}_{60} \mathrm{P}_{36} \mathrm{~K}_{60}$ & 28,4 & 12,84 & 3,65 & 24,0 & 12,64 & 3,03 \\
\hline & & & $\mathrm{N}_{176} \mathrm{P}_{157} \mathrm{~K}_{234}$ & 32,0 & 12.70 & 4,07 & 27,6 & 12,52 & 3,45 \\
\hline & & \multirow{3}{*}{$75 \times 19 \mathrm{~cm}$} & $\mathrm{~N}_{0} \mathrm{P}_{0} \mathrm{~K}_{0}$ & 23,1 & 13,16 & 3,04 & 25,3 & 12,95 & 3,28 \\
\hline & & & $\mathrm{N}_{60} \mathrm{P}_{36} \mathrm{~K}_{60}$ & 30,4 & 13,11 & 3,98 & 32,3 & 12,86 & 4,16 \\
\hline & & & $\mathrm{N}_{176} \mathrm{P}_{157} \mathrm{~K}_{234}$ & 36,8 & 12,95 & 4,77 & 35,1 & 12,75 & 4,47 \\
\hline \multirow{12}{*}{$10-12 \mathrm{~cm}$} & \multirow{6}{*}{$\begin{array}{c}\text { Без } \\
\text { обработки }\end{array}$} & \multirow{3}{*}{$75 \times 27 \mathrm{~cm}$} & $\mathbf{N}_{0} \mathbf{P}_{0} K_{0}$ & 16,7 & 13,01 & 2,16 & 18,2 & 12,91 & 2,35 \\
\hline & & & $\mathrm{N}_{60} \mathrm{P}_{36} \mathrm{~K}_{60}$ & 19,9 & 12,92 & 2,57 & 24,4 & 12,81 & 3,13 \\
\hline & & & $\mathrm{N}_{176} \mathrm{P}_{157} \mathrm{~K}_{234}$ & 21,2 & 12,78 & 2,71 & 28,2 & 12,70 & 3,59 \\
\hline & & \multirow{3}{*}{$75 \times 19 \mathrm{~cm}$} & $\mathbf{N}_{0} \mathbf{P}_{0} K_{0}$ & 19,0 & 13,12 & 2,49 & 26,3 & 13,03 & 3,42 \\
\hline & & & $\mathrm{N}_{60} \mathrm{P}_{36} \mathrm{~K}_{60}$ & 23,6 & 13,08 & 3,08 & 31,4 & 12,94 & 4,06 \\
\hline & & & $\mathrm{N}_{176} \mathrm{P}_{157} \mathrm{~K}_{234}$ & 26,8 & 12,90 & 3,46 & 34,0 & 12,83 & 4,36 \\
\hline & \multirow{6}{*}{$\begin{array}{c}\text { ТМТД, ТПС } \\
(2,5 \text { л/т) }\end{array}$} & \multirow{3}{*}{$75 \times 27 \mathrm{~cm}$} & $\mathbf{N}_{0} \mathbf{P}_{0} K_{0}$ & 22,5 & 12,94 & 2,91 & 21,5 & 12,90 & 2,77 \\
\hline & & & $\mathrm{N}_{60} \mathrm{P}_{36} \mathrm{~K}_{60}$ & 28,4 & 12,82 & 3,64 & 27,7 & 12,77 & 3,54 \\
\hline & & & $\mathrm{N}_{176} \mathrm{P}_{157} \mathrm{~K}_{234}$ & 32,9 & 12,68 & 4,17 & 32,3 & 12,64 & 4,08 \\
\hline & & \multirow{3}{*}{$75 \times 19 \mathrm{~cm}$} & $\mathbf{N}_{0} \mathbf{P}_{0} \mathbf{K}_{0}$ & 23,6 & 13,15 & 3,10 & 26,7 & 13,07 & 3,49 \\
\hline & & & $\mathrm{N}_{60} \mathrm{P}_{36} \mathrm{~K}_{60}$ & 30,6 & 13,06 & 4,00 & 35,1 & 12,93 & 4,54 \\
\hline & & & $\mathrm{N}_{176} \mathrm{P}_{157} \mathrm{~K}_{234}$ & 36,1 & 12,93 & 4,67 & 38,5 & 12,78 & 4,92 \\
\hline \multicolumn{4}{|c|}{$\mathrm{HCP}_{05}$} & 3,46 & 0,19 & 0,45 & 3,46 & 0,19 & 0,45 \\
\hline \multirow{2}{*}{\multicolumn{4}{|c|}{$\frac{\mathrm{HCP}_{05}(\mathrm{~A}, \mathrm{~B}, \mathrm{C}, \mathrm{D})}{\mathrm{HCP}_{05}(\mathrm{E})}$}} & 0,71 & 0,04 & 0,09 & 0,71 & 0,04 & 0,09 \\
\hline & & & & 0,86 & 0,05 & 0,11 & 0,86 & 0,05 & 0,11 \\
\hline
\end{tabular}

Глубина заделки семенного материала оказывает непосредственное влияние на процессы прорастания клубней и все последующие этапы роста и развития картофельного растения [18-19]. В нашем опыте при первом сроке посадки (17-20 мая) мелкая заделка семенных клубней ускоряла появление всходов (на 2-3 дня) и увеличивала ассимиляционную поверхность листьев (на $18 \%$ ), что создавало более благоприятные условия для развития растений и накопление в клубнях крахмала. Крахмалистость клубней в этом варианте была достоверно (в среднем на $0,04 \%$ ) больше, чем при глубокой посадке, тогда как урожайность картофеля не изменялась.

При поздней посадке благоприятные условия для прорастания клубней, роста и формирования картофельного растения создаются при большей глубине заделки семенного материала [20]. В нашем опыте посадка картофеля 1-5 июня на глубину 10-12 см обеспечивала не только существенную прибавку урожая $(2,70$ т/га), но и крахмалистости клубней - на $0,10 \%$ по сравнению с вариантом мелкой заделки семенных клубней.

Степень влияния глубины посадки на содержание крахмала зависела от погодных условий вегетационного периода и срока посадки. Так, в благоприятных условиях 2011 г. глубокая посадка 17 мая способствовала снижению этого показателя в среднем на $0,09 \%$, а 1 июня, наоборот, повышала его в среднем на $0,16 \%$ по сравнению с мелкой заделкой семенных клубней. В засушливом 2012 г. посадка картофеля на глубину 10-12 см обеспечивала большую крахмалистость клубней как при первом (на $0,10 \%$ ), так и при втором сроках (на $0,14 \%$ ). Тогда как в 2013 г. увеличение глубины заделки семенного картофеля с 5-6 до 10-12 см при посадке 20 мая снижало содержание крахмала в клубнях на 0,13\%, а при посадке 6 июня этот показатель не изменялся $(+0,01 \%)$. 
Загущение посадок с 49,3 до 70,1 тыс./га не только увеличивало урожай картофеля в среднем на 4,55 т/га (19,5\%), но и способствовало повышению крахмалистости клубней на $0,17 \%$. Эффект от загущения возрастал при использовании протравленного семенного материала для посадки 17-20 мая (прибавка - 0,23 \%) и снижался при посадке непротравленных клубней 1-5 июня (прибавка $-0,13 \%$ ).

В среднем за 2011-2013 гг. формирование программируемой урожайности 25 т/га обеспечили варианты с использованием протравленного семенного материала - от 23,97 до 35,11 т/га в зависимости от срока, глубины и густоты посадки. На фоне применения удобрений, рассчитанных на получение урожая 40 т/га, фактическая урожайность картофеля составляла от 58,5 до 96,3 \% от заданной. Это объясняется неблагоприятными метеорологическими факторами в два года исследований из трех. Максимальный результат достигался при поздней загущенной посадке с заделкой протравленных семенных клубней на глубину 10-12 см.

Дисперсионный анализ многофакторного полевого опыта показал, что урожайность картофеля в лесостепной зоне Южного Урала зависела в основном от уровня минерального питания (вклад фактора - 30,2 \%), протравливания семенного материала $(27,8 \%)$ и густоты посадки $(21,5 \%)$, достоверно, но в меньшей степени - от срока $(5,1 \%)$ и глубины посадки $(1,7 \%)$, а также от взаимодействия факторов А и С (срок посадки и протравливание семенных клубней $-5,2 \%$ ), А и D (срок и густота посадки - 3,1\%), А и В (срок и глубина посадки $1,8 \%$ ).

Крахмалистость клубней сорта Тарасов зависела главным образом от густоты посадки (сила влияния фактора - 31,2 \%), срока посадки $(27,6 \%)$, уровня питания $(22,5 \%)$, взаимодействия факторов А и В (срок и глубина посадки $-5,6 \%$ и и не зависела от обработки семенного картофеля фунгицидами $(0,9 \%)$ и глубины посадки $(0,6 \%)$. Влияние срока и глубины посадки возрастало в условиях недостаточно влажного 2012 года, когда эти факторы обуславливали соответственно 31,5 и 7,8 \% вариации содержания крахмала в клубнях. Роль протравливания семенного материала возрастала во влажных условиях 2011 года до 26,9\%.

Наибольший сбор крахмала с единицы площади обеспечивала загущенная посадка на фоне удобрений под урожай 40 т/га с заделкой протравленного семенного материала на глубину 5-6 см при первом сроке посадки $(4,77$ т/га) и на 10-12 см - при втором (4,92 т/га). Этот показатель в равной степени зависел от протрав- ливания семенных клубней (вклад фактора $27,6 \%)$, уровня питания $(27,5 \%)$ и густоты посадки $(25,2 \%)$, в меньшей степени - от срока $(3,8 \%)$ и глубины посадки $(1,9 \%)$. Достоверное влияние на сбор крахмала оказывало взаимодействия факторов $\mathrm{AB}$ (срок и глубина посадки - 2,2\%), АС (срок посадки и протравливание клубней $-5,2 \%$ ) и $\mathrm{AD}$ (срок и густота посадки $-3,0 \%)$.

\section{Выводы.}

1. Агроклиматические условия лесостепной зоны Южного Урала гарантируют получение планируемой урожайности картофеля 25 т/га, а при достаточном обеспечении вегетационного периода осадками - 40 т/га. Для этого необходимо применять сбалансированные дозы минеральных удобрений, протравленный семенной материал с заделкой на глубину 5-6 cм при посадке 17-20 мая и на глубину 10-12 см при поздней посадке (1-5 июня).

2. Мелкая заделка семенного материала (на глубину 5-6 см) при посадке 17-20 мая и глубокая (на 10-12 см) - при посадке 1-5 июня способствуют увеличению содержания крахмала в клубнях на 0,04 и 0,10 \% соответственно.

3. Посадка картофеля во второй декаде мая обеспечивает повышение крахмалистости клубней в среднем на $0,16 \%$ по сравнению с поздней посадкой. Преимущество ранней посадки возрастает при мелкой заделке семенных клубней (до 0,23 \%), а при заделке клубней на глубину 10-12 см оно составляет в среднем $0,09 \%$.

4. Протравливание семенного материала фунгицидом ТМТД, ТПС (2,5 л/т) при первом сроке посадки повышает урожайность картофеля - в среднем на 7,42 т/га (34,7 \%), а при втором - на 2,92 т/га, тогда как крахмалистость клубней при этом снижалась в среднем на 0,05 и $0,02 \%$ соответственно.

5. Загущение посадок с 49,3 до 70,1 тыс. клубней на 1 га увеличивает как урожайность картофеля (на 4,55 т/га или 19,5\%), так и крахмалистость клубней (на $0,17 \%$ ).

6. Оптимальным сочетанием агротехнических приемов для получения планируемой урожайности картофеля 40 т/га является загущенная посадка протравленным семенным материалом на глубину 5-6 см при первом сроке посадки (17-20 мая) и на 10-12 см - при втором (1-5 июня) на фоне внесения соответствующей дозы удобрений. Этот комплекс агроприемов позволяет получать урожай клубней на уровне $36,8-38,5$ т/га с содержанием крахмала $(12,8-$ $13,0 \%)$, незначительно отличающимся от контроля $(13,1 \%)$ при максимальном сборе крахмала с единицы площади (4,77-4,92 т/га). 


\section{Библиографический список}

1. Мингалев, С.К. Реакция сортов на разные виды удобрений [Текст] / С.К. Мингалев // Аграрный вестник Урала. 2014. № 7. С. 74-76.

2. Шанина, Е.П. Селекция картофеля на качественные показатели [Текст] / Е.П. Шанина, Е.М. Клюкина, В.П. Кокшаров // Аграрный вестник Урала. 2009. № 11 (65). С. 84-85.

3. Галеев, Р.Р. Картофель в Западной Сибири [Текст]: учебное пособие / Р.Р. Галеев, Н.П. Щербинин. Новосибирск: Новосибирский СХИ, 1991. $60 \mathrm{c.}$

4. Владимиров, В.П. Агротехнические приемы повышения продуктивности картофеля на серой лесной почве лесостепи Среднего Поволжья [Текст] / В.П. Владимиров, М.Т. Гайнутдинов, В.И. Аппаков // Вестник Казанского государственного аграрного университета. 2012. № 1 (23). C. 119-124.

5. Васильев, А.А. Сбалансированность минерального питания определяет урожайность и качество картофеля [Текст] / А.А. Васильев // Вестник Россельхозакадемии. 2013. № 4. С. 21 23.

6. Горбунов, А.К. Влияние сроков посадки на ассимиляционную поверхность листьев и урожайность картофеля [Текст] / А.К. Горбунов // АПК России. 2014. Т. 67. № 1. С. 74-79.

7. Мингалев, С.К. Реакция различных сортов картофеля на сроки посадки в Свердловской области [Текст] / С.К. Мингалев // Аграрный вестник Урала. 2014. № 6. С. 47-51.

8. Методика исследований по культуре картофеля [Текст]. М.: НИИКХ, 1967. 262 с.

9. Доспехов, Б.А. Методика полевого опыта [Текст] / Б.А. Доспехов. М. Агропромиздат, $1985.351 \mathrm{c}$.

10. Методика физиолого-биохимических исследований картофеля [Текст]. М.: НИИКХ, 1989. 142 c.
11. Дмитриева, 3.А. Оптимальные сроки и густота посадки [Текст] / 3.А. Дмитриева // Картофель и овощи. 1985. № 2. С. 15-17.

12. Чамышев, А.В. Агроэкологическое обоснование сроков посадки картофеля в Саратовском правобережье [Текст] / А.В. Чамышев // Аграрный научный журнал. 2016. № 2. С. 32-33.

13. Горбунов, А.К. Влияние комплекса агротехнических приемов на урожайность картофеля в лесостепи Южного Урала [Текст] / А.К. Горбунов // Вестник Бурятской государственной сельскохозяйственной академии им. В.Р. Филиппова. 2014. № 2 (35). С. 35-40.

14. Защита картофеля от болезней, вредителей и сорняков [Текст] / Б.В. Анисимов, Г.Л. Белов, Ю.А. Варицев [и др.]. М.: Картофелевод, 2009. $272 \mathrm{c.}$

15. Зиганшин, А.А. Программирование урожаев, результативность удобрений и орошения [Текст] / А.А. Зиганшин, Л.Р. Шарифуллин // Вестник сельскохозяйственной науки. 1979. № 7. C. 26-32.

16. Васильев, А.А. Оптимизация технологии возделывания картофеля на Южном Урале [Текст]: автореф. ... дис. доктора с.-х. наук / А.А. Васильев. Уфа, 2015. 50 с.

17. Шатилов, И.С. Экологические, биологические и агротехнические условия получения запланированных урожаев [Текст] / И.С. Шатилов // Известия ТСХА. 1970. Вып. 1. С. 60-66.

18. Ганзин, Г.А. Сроки посадки и урожай [Текст] / Г.А. Ганзин, А.Х. Абазов // Картофель и овощи. 1984. № 3. С. 15-16.

19. Горбунов, А.К. Влияние глубины посадки на урожайность клубней картофеля сорта Тарасов [Текст] / А.К. Горбунов // АПК России. 2013. T. 63. C. $95-100$.

20. Писарев, Б.А. Сортовая агротехника картофеля [Текст] / Б.А. Писарев. М. Агропромиздат, 1990. 208 с.

\section{Сведения об авторах}

1. Горбунов Анатолий Константинович, заведующий лабораторией элитного семеноводства картофеля, ФГБНУ Южно-Уральский научно-исследовательский институт садоводства и картофелеводства, г. Челябинск, Россия. E-mail: kartofel_chel@mail.ru.

2. Васильев Александр Анатольевич, доктор сельскохозяйственных наук, ученый секретарь, ФГБНУ Южно-Уральский научно-исследовательский институт садоводства и картофелеводства, г. Челябинск, Россия. E-mail: kartofel_chel@mail.ru.

В настоящее время урожайность картофеля в Челябинской области, несмотря на высокий биологический потенциал возделываемых сортов (40-50 т/га), остается невысокой (15 т/га). В комплексе мероприятий, направленных на по- вышение продуктивности культуры и повышение качества клубней важную роль в нашем регионе играют возделывание адаптивных сортов, сбалансированное минеральное питание, оптимальная густота и сроки посадки картофе- 
ля. Целью наших исследований являлся подбор оптимального сочетания агротехнических факторов для получения планируемой урожайности картофеля с высокой крахмалистостью клубней. Исследования позволили выделить оптимальные сочетания агроприемов, обеспечивающих получение планируемого урожая картофеля 40 т/га.

\author{
A. Gorbunov, A. Vasiliev
}

\title{
POTATO TUBER PRODUCTIVITY AND STARCH CONTENT IN THE FOREST STEPPE OF CHELYABINSK REGION DEPENDING ON CULTURE PRACTICE
}

Key words: potatoes; tuber starch content; planting time and depth; alimentation area and rate; seed treatment.

\section{Authors' personal details}

1. Gorbunov Anatoly, Head of the Laboratory of elite seed potatoes, State Scientific Institution South Ural Research Institute of Horticulture and Potato Planting. Chelyabinsk, Russia. E-mail: kartofel_chel@ mail.ru.

2. Vasiliev Alexander, Doctor of Agricultural Sciences, Scientific Secretary. State Scientific Institution South Ural Research Institute of Horticulture and Potato Planting, Chelyabinsk, Russia. E-mail: kartofel_chel (a)mail.ru.

Currently, potato yields in the Chelyabinsk region are low (15 t/ha) though cultivated varieties have high biological potential (40-50 t/ha). A complex of measures to improve crop productivity and tuber quality cultivation of adaptive varieties, balanced mineral nutrition, optimum density and potato planting timing play an important role in our

(C) Горбунов А.К., Васильев А.А. region. The aim of our research was to select the right set of agronomic factors to get the planned potato yield with high starch content of tubers. The research made it possible to identify the optimal combination of agronomic practices to ensure the planned yield of $40 \mathrm{t} / \mathrm{ha}$. 